Hooimeijer, P., \& Schutjens, V.A.J.M. (1991). Changing life-styles and housing consumption: a longitudinal approach. Netherlands journal of housing and the built environment., 6(2), 143-158. 


\title{
CHANGING LIFESTYLES AND HOUSING CONSUMPTION: A LONGITUDINAL APPROACH
}

\author{
Pieter Hooimeijer and Veronique Schutjens
}

\section{Introduction}

Classical theory argues that changes in housing demand occur in response to developments during the course of the life cycle (Rossi, 1955) and the labour career (Leslie and Richardson, 1961). In adjusting one's housing situation to an increasing need for space as a result of a growing household or to rising aspirations as a result of the growth in household income, a housing career evolves. As both the life cycle and the labour career are strongly associated with the age of the household head, many empirical studies have uncovered a strong statistical relationship between the age structure of a population and its aggregate pattern of housing demand. This has led researchers to believe that future patterns of housing demand can be derived from predictions of changes in the age structure. This approach is essentially static; it does not allow for any changes in age-specific housing demand over time because it implicitly assumes that the progression over the life cycle is identical for each subsequent birth cohort.

An alternative concept argues that patterns of housing consumption can be related to differences in lifestyle. In the year Rossi published his seminal work, Shevky and Bell introduced three broad lifestyle categories: careerism, familism and consumerism. Household location (urban or suburban) and the proportion of the household budget spent on housing could be related to these lifestyle groups. From then on, many studies of lifestyle have been published. In March 1990 a study published in a Dutch financial journal identified sixteen sociolifestyle groups within the European consumer population. The approach taken in this study was also cross-sectional. Its central aim was to identify the differences within the consumer population at a given moment. In this respect the approach was also comparatively static. A clear idea about what generates shifts in the distribution of lifestyle groups over time is lacking.

If cross-sectional lifestyle studies teach us anything, it is that lifestyle changes come as a surprise. An application of these studies to housing is therefore problematic. Housing is concerned with long-term investments and the housing

Neth. J. of Housing and the Built Environment, Vol. 6 (1991) No. 2. 
market is inflexible by nature, both in terms of responses to shifts in demand for specific types of housing and to shifts in the spatial concentration of demand. Not surprisingly, many housing researchers have rejected the lifestyle approach in favour of the more classical concept of changes in housing demand as a response to the progression over the life cycle. Some have even tried to incorporate the changes in lifestyle into this framework by stressing that the dominant orientation in the early stages of the life cycle is one of careerism, followed by familism in the expansion stages, and by consumerism in the reduction stages, when household income is still high and the children have left the parental home.

In this paper we shall adopt a different strategy by looking at lifestyle dynamics from a longitudinal perspective. We define lifestyle as the expression of values with respect to work, living arrangements and consumption. Living arrangements refer to the composition of the household. We shall show that changes in housing preferences can be explained by changes in living arrangements, that changes in living arrangements within a cohort can be explained by the progression over the life cycle, that changes between cohorts can be explained by changes in lifestyle, and that a combination of intra- and inter-cohort analyses might lead to better forecasts of future housing preferences. The basic assumption of this paper is that attitudes become relatively fixed early in adult life. This assumption has been confirmed by De Feijter's recent empirical analyses of sexuality and fertility (De Feijter, 1991). By the age of thirty most people will have made decisions concerning such basic questions as whether or not to have children, the importance of work, etc. These decisions have a lasting effect on the remainder of their life course. The educational level attained and the first job acquired determine the future labour career to a large extent. When the last child is born will have a decisive impact on the age at which the "empty nest" stage in the life cycle is reached in the future. Looking at one (birth)cohort, the changes in consumption patterns over time are less a matter of changing values and norms, but result from changes in the constraints on consumption behaviour, which might be quite predictable once the decisions made earlier in life are known.

This also implies, however, that successive cohorts will differ to a large extent, both in the values they hold and in the way their life courses develop; they will also therefore differ in their consumption pattern. An awareness of the changes operating when households are established is highly indicative of their future consumption patterns. In short, tomorrow's old will resemble today's young more than they will resemble today's old.

In this paper we shall first show the inadequacy of the cross-sectional lifecycle approach to housing demand by illustrating the changing decisions successive cohorts have made with respect to their living arrangements. These changes can be seen as an expression of the shift towards individualization. Next we shall analyse a series of cohorts and show that the differences in age-specific housing demand of successive cohorts can be explained to a large extent by changes in living arrangements. 

demand

The dominant trend in housing policy in the Netherlands has been to improve the quality of the housing stock by ensuring the high quality of new housing. The idea behind this was that households would spend (part of) their rising incomes on increasing the level of their housing consumption by moving into these new dwellings, vacating their more modest and cheaper dwellings at the beginning of their labour and housing careers. This policy is an expression of Ratcliff's observation that "households filter up, while houses filter down" (Ratcliff, 1949).

For a long time this policy was successful. The proportion of total housing accounted for by the owner-occupied sector rose from $26 \%$ in 1947 to $43 \%$ in 1985. In the rented sector, many large dwellings were added to the stock. This policy presupposes, however, an evolutionary household development in a period of ongoing economic prosperity. Increasing family size coupled with the desire for more space per person and increases in income with which to fulfil these aspiration should prompt people to leave their urban houses and move to singlefamily dwellings in the suburbs and, particularly, the new towns. During the 1970 s it became clear that neither of these was happening. Household development deviated from the traditional sequence of life-cycle stages to an increasing extent.

The first change involved the age at which young people left their parental homes. The average age at which this occurred fell from 25 in 1955 to 23 in 1971, where it has since tended to remain. The fall in the age at leaving the parental home resulted in a substantial increase in the demand for dwellings during the 1960s. Policy makers were taken by surprise by this development. It was not clear how this trend would develop in the future. The magnitude of these changes becomes clear if we compare two birth cohorts (Figure 1). Of the women born in the period $1935-39$, more than $80 \%$ still lived with their parents at the age of 20 . Of the women born in $1955-59$ only $50 \%$ of those aged 20 still lived with their parents. As the figure shows, the decrease in the proportion in each age group still living at home shows a regular pattern. Knowing the percentage still living at home at the age of 20 gives a good indication of the percentage living with their parents at the age of 24 or later. A longitudinal analysis of trends does improve one's ability to predict future changes and is therefore useful in deciding policy.

The second change involved the sudden drop in fertility rates, shown in Table 1. This table clearly illustrates the changes in household size which occurred in the 1960s and 1970s. During the 1960s the number of children born to families fell. The birth rates of two-parity and three-parity women decreased, but the number of women having their first or second child remained constant, and even increased to some extent. In the 1970s, especially, the proportion of women without children increased. Not only did women have fewer children, more women had no children at all. As a result, the number of young couples (under 45) having children nearly stabilized during the 1970s, despite the growth 
Figure 1 Percentage of women living with parents, by age and birth cohort

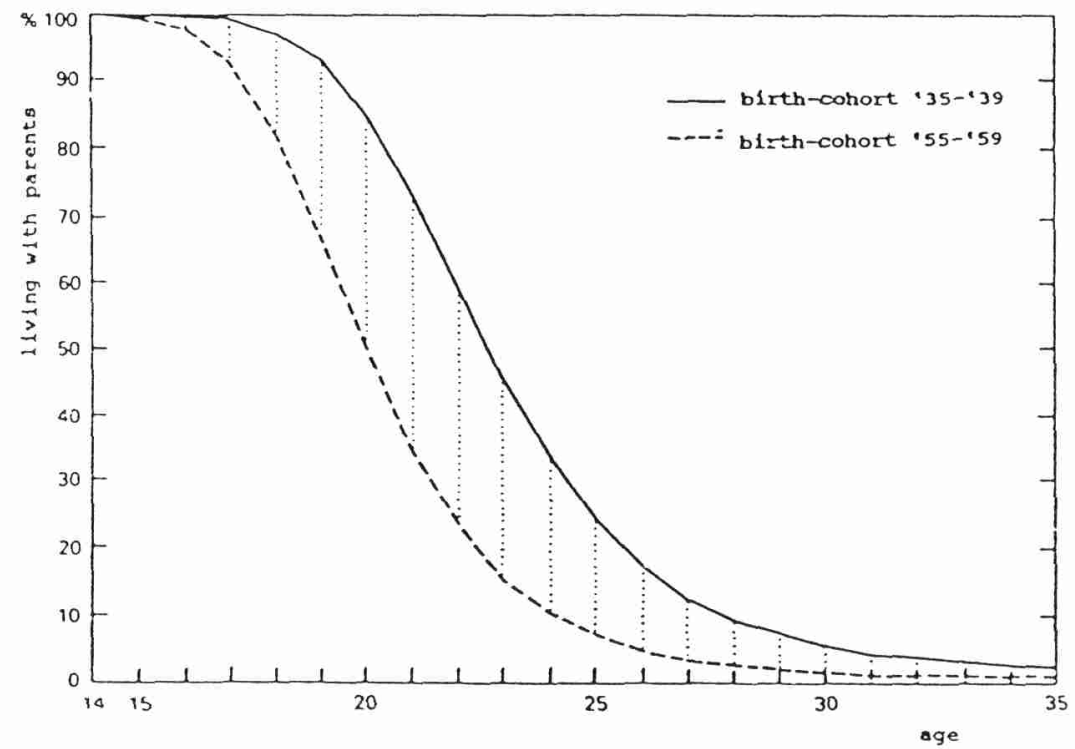

Source: Housing Needs Survey 1981 (WBO 1981)

in the number of 25-45 year olds. The rates shown are measured crosssectionally. In retrospect the trend seems to be obvious. There were clearly changes in the value attached to having children. From these rates, however, it is hard to predict future developments. As various demographers have illustrated (e.g. Newel, 1988), the accuracy of predictions of future levels of fertility can be enhanced by adopting cohort-specific measures of fertility. Modern population projections in developed countries use cohort-specific parity progression rates.

Table 1 Number of live births per '000 women (parity rates), 1960-80

\begin{tabular}{|c|c|c|c|c|c|}
\hline \multirow[b]{2}{*}{ Year } & \multicolumn{5}{|c|}{ Parity } \\
\hline & 1 & 2 & 3 & 4 & Total \\
\hline 1960 & 31.9 & 27.8 & 17.0 & 25.7 & 102.4 \\
\hline 1965 & 33.9 & 27.3 & 15.8 & 18.9 & 95.9 \\
\hline 1970 & 34.5 & 29.6 & 13.6 & 10.6 & 88.4 \\
\hline 1975 & 26.7 & 24.1 & 6.7 & 3.4 & 60.8 \\
\hline 1980 & 24.5 & 21.1 & 7.8 & 3.4 & 56.9 \\
\hline
\end{tabular}

Source: CBS 


\section{Figure 2 Trends in age-specific divorce rates}

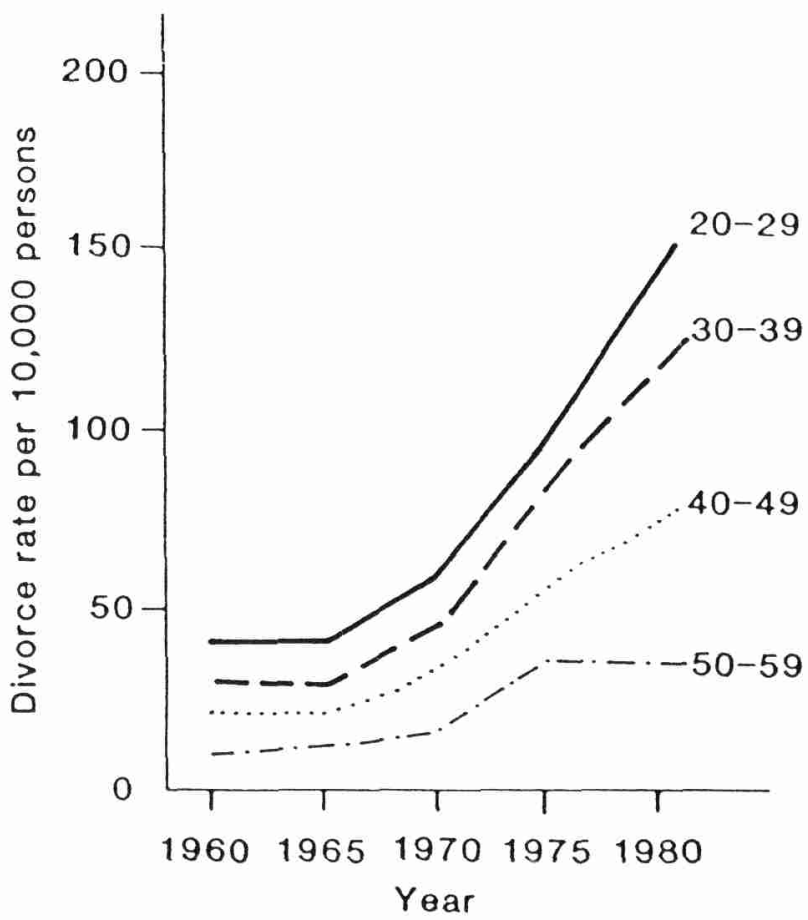

Source: CBS

The third change was the rise in divorce rates. The change in age-specific divorce rates is illustrated in Figure 2. As can be seen from this figure, the divorce rate began to increase significantly in the second half of the 1960s, but it was in the 1970s that divorce rates rose most steeply. The introduction of more permissive legislation in 1971 might have encouraged this trend, but it was more a response to changing attitudes towards marriage than a cause of this trend (De Hoog, 1979; and Frinking, 1981). Figure 2 also indicates that the rise in divorce rates varied by age group. Obviously the young were more receptive to ideas about divorce. Again, this supports the assumption that people in the early phases of adult life are influenced by changes in attitudes towards moral questions to a larger extent than people in their thirties or forties.

The rapid increase in the number of divorces could have been counterbalanced if remarriage rates had increased as well. This did not happen however. On the contrary, there was a fall in the rate of remarriage in the Netherlands. As a result, the number of divorcees has grown considerably over the last two decades. 
Table 2 Number of households containing only one person, 1971-2000

\begin{tabular}{lrrrr}
\hline Households ('000s) & 1971 & 1980 & 1989 & $2000^{*}$ \\
\hline Solitaries & 650 & 1085 & 1764 & 2500 \\
& $16.5 \%$ & $21.7 \%$ & $29.3 \%$ & $37.5 \%$ \\
Others & 3400 & 3921 & 4262 & 4170 \\
& $83.5 \%$ & $78.3 \%$ & $70.7 \%$ & $62.5 \%$ \\
\hline Total & 4050 & 5006 & 6026 & 6670 \\
& $100.0 \%$ & $100.0 \%$ & $100.0 \%$ & $100.0 \%$ \\
\hline
\end{tabular}

Source: CBS

*Hooimeijer and Linde (1988)

The fourth change in the development of the household has been the growing tendency to live apart. Not only have remarriage rates fallen, but rates of first marriage have also declined. Until 1980 this tendency was compensated for by the fact that more people began to cohabit without necessarily being married. After 1980 the numbers cohabiting also fell. Of those women born between 1950-54, by the age of 21 almost $37 \%$ were living with their (wedded) partner. Of those women born between 1960 and 1964, only 28\% were living with their (wedded) partner by the same age. People had obviously either postponed cohabiting or decided to live alone.

All the four changes mentioned above can be seen as the manifestation of the process of individualization. This term is really a shorthand for the decline of a single dominant culture and the rise of and the co-existence of various patterns of norms in general, and of patterns of living arrangements in particular (De Feijter, 1991). The result of these changes in household development has been an enormous increase in the number of one- and two-person households, a trend which is expected to continue in the near future. Average household size has declined from more than 3.0 in 1971 to less than 2.5 in 1989. In Table 2 the total number of households and the proportion of households containing only one person is given.

In 1971 the majority of households consisted of (married) couples with dependent children (2.4 million out of 4.0 million households). In 2000 such families will be in a minority (1.8 million out of 6.67 million households). By 1980 nearly half of all households consisted of one or two persons. The traditional sequence of life-cycle stages has become an exception rather than the norm. The general trend towards increasing numbers of growing families needing more spacious dwellings has been reversed.

The reversal of this trend was exacerbated by the onset of economic recession in the late 1970 s and early 1980s. The result was a switch in housing demand from family dwellings in suburban areas to flats in the cities. The traditional idea of a housing career starting in cheap housing in the city and ending in expensive family housing in the suburb was largely rendered obsolete. 
This trend towards re-urbanization began in the mid-1970s (Hoogvliet and Jobse, 1989) and, as the figures in Table 2 indicate, can be expected to continue in the future.

The standard life-cycle approach to housing demand is inadequate because it supposes that successive birth cohorts follow an identical sequence of stages during the life course. This assumption is clearly untenable since one has to allow for variations in lifestyle between successive cohorts. The lifestyle approach lacks a historical dimension however. New lifestyle groups appear; "Yuppies" (young urban professionals) and "Dinkies" (double income, no kids) are recent phenomena. These labels always explicitly or implicitly refer to the demographic characteristics of the household and, in particular, to the household composition. If lifestyle grouping is pertinent to housing demand, then we can assume that, if we are able to predict the living arrangements of the future population, we can also infer the (housing) consumption of these groups in the future.

\section{Inter-cohort shifts in housing preferences: changing lifestyles, the choice of a new generation?}

To test the assumption that changes in the age-specific pattern of preferred housing can be related to trends in the living arrangements of successive cohorts, we analysed six birth cohorts at two points in time. The data were derived from the Woningbehoefteonderzoek (WBO) (Housing Needs Survey). This survey is conducted every four years and contains questions on the characteristics of the households involved and on their present and preferred housing situation. Housing preferences are measured by the stated preference of households wanting to move. In our analyses we chose to concentrate on preferences for a flat or a single-family dwelling. We decided to choose these because they correspond closely with either urban or suburban and rural locations, which are in turn closely tied to general ideas about new lifestyle groups. Before turning to housing demand, however, we shall first illustrate the changes that have taken place in household development from a life-cycle point of view by following six birth cohorts over a period of five years. Then we shall discuss the differences between cohorts, illustrating the changing attitudes of successive cohorts towards living arrangements.

The figures in Table 3 show that important shifts occurred in household composition within birth cohorts between 1977 and 1985. This is to be expected as each cohort progresses through the life cycle. Changes can easily be interpreted in terms of transitions to the next stage in this cycle.

Cohort a was born in the period 1947-54. In 1977 these people were aged between 23 and 30 . In that year $41 \%$ of them were living as a couple with children. Eight years later, when these households were in their thirties, this percentage had risen to $63 \%$, due to the fact that many women had their first child during this period. Because of divorce the number of one-parent families also increased in this period. The increase in the number of those living alone 
seems spectacular, but to a large extent this can be ascribed to new households (the number of households increased from 600,000 to nearly a million). Those leaving the parental home at relatively high ages have a large probability of becoming single (Hooimeijer and Linde, 1988). The pattern typically resembles the household formation and child-bearing stage of the life cycle (Glick, 1957).

Cohort b, born in 1939-46, was aged between 31 and 38 in 1977. This cohort shows little change in its household type distribution in the eight years after 1977. The number of households with children was almost stable at around $80 \%$, although the proportion of one-parent families increased due to divorce. This was also the reason for the slight increase in the proportion of those living alone. This stable pattern is indicative of a stage of consolidation.

Cohort c corresponds to the age group 39-46 in 1977. The proportion of households with co-residing children fell for this cohort, as can be seen from the table. This corresponds to the stage of child-launching (Hooimeijer and Dieleman, 1986). The percentage of households having co-residing children fell to less than $70 \%$. The rise in the number of solitaries is due to the cumulative effects of low remarriage rates after divorce and (to a limited degree) to early widowhood. The death of a spouse becomes increasingly important in explaining the changes in the household structure of cohorts $\mathbf{d}$ and $\mathbf{e}$. The number of solitaries increased rapidly, and, as children continued to leave the parental home, so too did the number of couples without co-resident children.

Within each cohort household development follows a general pattern, and one which seems highly predictable as long as the transition between stages of the life cycle can be estimated accurately. The successive cohorts do not differ much in size, except in the case of the youngest (the post-war baby-boom generation). If housing preferences were dependent on household composition only, this would lead to a stable pattern of housing demand over the years. As

Table 3 Household composition by cohort in 1977 and 1985 (\%)

\begin{tabular}{|c|c|c|c|c|c|c|}
\hline & $\begin{array}{l}\text { Cohort A } \\
1947-1954\end{array}$ & $\begin{array}{l}\text { Cohort B } \\
1939-1946\end{array}$ & $\begin{array}{r}\text { Cohort C } \\
1931-1938\end{array}$ & $\begin{array}{l}\text { Cohort D } \\
1923-1930\end{array}$ & $\begin{array}{l}\text { Cohort E } \\
1915-1922\end{array}$ & Total \\
\hline $\begin{array}{l}\text { Household } \\
\text { composition }\end{array}$ & 19771985 & 19771985 & 19771985 & 19771985 & 19771985 & 19771985 \\
\hline Solitaries & 9.416 .0 & 7.011 .0 & 4.813 .5 & $\begin{array}{ll}5.9 & 20.2\end{array}$ & 11.635 .1 & 7.618 .1 \\
\hline Couples & $46.5 \quad 13.5$ & $13.6 \quad 7.2$ & 7.216 .1 & 13.936 .7 & $34.0 \quad 47.3$ & 22.121 .9 \\
\hline Fam. with child & 41.363 .0 & 75.871 .3 & 83.059 .5 & 73.434 .2 & 46.412 .4 & 65.151 .3 \\
\hline One-parent fam. & $1.6 \quad 6.4$ & 3.18 .8 & $4.3 \quad 8.8$ & $5.7 \quad 7.1$ & $6.8 \quad 4.0$ & 4.27 .1 \\
\hline Multi-family & 1.21 .1 & $0.5 \quad 1.7$ & $0.8 \quad 2.1$ & $\begin{array}{ll}1.2 & 1.8\end{array}$ & $\begin{array}{ll}1.1 & 1.2\end{array}$ & $0.9 \quad 1.6$ \\
\hline $\begin{array}{l}\text { No. of households } \\
(' 000 \text { s) }\end{array}$ & 591994 & 835839 & $626 \quad 672$ & $\begin{array}{ll}616 & 647\end{array}$ & 602583 & 32703735 \\
\hline
\end{tabular}

Sources: WBO 1977, WBO 1985 
Table 4 Household composition by age group in 1977 and 1985 (\%)

\begin{tabular}{|c|c|c|c|c|c|c|c|c|c|c|c|c|c|c|}
\hline \multirow{2}{*}{$\begin{array}{l}\text { Household } \\
\text { composition }\end{array}$} & \multicolumn{2}{|c|}{ Age $23-30$} & \multicolumn{2}{|c|}{ Age $31-38$} & \multicolumn{2}{|c|}{ Age $39-46$} & \multicolumn{2}{|c|}{ Age $47-54$} & \multicolumn{2}{|c|}{ Age $55-62$} & \multicolumn{2}{|c|}{ Age $63-70$} & \multirow[b]{2}{*}{1977} & \multirow{2}{*}{$\begin{array}{l}\text { Total } \\
1985\end{array}$} \\
\hline & 1977 & 1985 & 1977 & 1985 & 1977 & 1985 & 1977 & 1985 & 1977 & 1985 & 1977 & 1985 & & \\
\hline Solitaries & 9.4 & 29.3 & 7.0 & 16.0 & 4.8 & 11.0 & 5.9 & 13.5 & 11.6 & 20.2 & 23.7 & 35.1 & 9.8 & 20.1 \\
\hline Couples & 46.5 & 38.0 & 13.6 & 13.5 & 7.2 & 7.2 & 13.9 & 16.1 & 34.0 & 36.7 & 50.2 & 47.3 & 25.9 & 24.7 \\
\hline Fam. with child & 41.3 & 27.6 & 75.8 & 63.0 & 83.0 & 71.3 & 73.4 & 59.5 & 46.6 & 34.2 & 18.9 & 12.4 & 58.9 & 47.1 \\
\hline One-parent fam. & 1.6 & 3.8 & 3.1 & 6.4 & 4.3 & 8.8 & 5.7 & 8.8 & 6.8 & 7.1 & 5.4 & 4.0 & 4.4 & 6.5 \\
\hline $\begin{array}{l}\text { No. of households } \\
(' 000 \mathrm{~s})\end{array}$ & 591 & 802 & 835 & 994 & 626 & 839 & 616 & 672 & 602 & 647 & 510 & 583 & 3780 & 4537 \\
\hline
\end{tabular}

Sources: WBO 77, WBO 1985 
mentioned above, the traditional cross-sectional life-cycle approach assumed a stable household composition by age category. Future housing demand could then be derived from a simple population projection.

Table 3 indicates that there were substantial differences between successive cohorts at comparable ages however. For instance, in the case of cohort a in 1985, when the members of this cohort were aged between 31 and $3816 \%$ of households consisted of solitaries. The corresponding figure for cohort $\mathbf{b}$ when its members were aged 31 to 38 was only $7 \%$. To try and explain these cohort differences the data presented in Table 3 have been rearranged to enable a direct comparison between the same age group at different points in time. These reworked data are presented in Table 4. Table 4 extends Table 3 by including the age group 23-30 in 1985 (that is, those born between 1955 and 1962) and by including the age-group 63-70 in 1977 . The age-group $23-30$ shows a significantly different household structure from that of previous cohorts. In 1985 almost $30 \%$ of households in this group consisted of solitaries, compared with less than $10 \%$ of households aged 23-30 in 1977. This is the result of the recent tendency among those born after 1955 to live alone rather than as a couple when leaving the parental home. Fertility is also lower among this cohort, due to the increase in the age at which couples have their first child. The higher percentage of solitaries among those aged 31-46 is a result of the rising rate of divorce in the 1970s. The decreasing percentage of households in the age group 47 and over with children is due to the declining number of children per household, combined with the decreasing age at which children leave the parental home. The increasing number of the elderly living alone is due particularly to the widening in the difference in male and female life expectations.

As is obvious from table 4, age-specific household composition is dynamic over time, because of the changes in values and norms with respect to living arrangements - the process of individualization discussed earlier. A stable pattern of housing demand can therefore not be expected. This does raise the question, however, of whether changes in aggregate demand can be explained by these changes in household composition between cohorts.

Table 5 Housing preference by age group in 1977 and 1985 (\%)

\begin{tabular}{|c|c|c|c|c|c|c|c|c|c|c|c|c|}
\hline \multirow{2}{*}{$\begin{array}{l}\text { Preferred } \\
\text { housing }\end{array}$} & \multicolumn{2}{|c|}{ Age 23-30 } & \multicolumn{2}{|c|}{ Age $31-38$} & \multicolumn{2}{|c|}{ Age $39-46$} & \multicolumn{2}{|c|}{ Age $47-54$} & \multicolumn{2}{|c|}{ Age $55-62$} & \multicolumn{2}{|c|}{ Age $63-70$} \\
\hline & 1977 & 1985 & 1977 & 1985 & 1977 & 1985 & 1977 & 1985 & 1977 & 1985 & 1977 & 1985 \\
\hline Flat & 14.5 & 27.3 & 13.2 & 19.0 & 13.0 & 20.0 & 21.0 & 32.2 & 33.3 & 42.1 & 51,9 & 58.1 \\
\hline Single-fam. housing & 85.5 & 72.8 & 86.8 & 81.0 & 87.0 & 80.1 & 78.9 & 67.8 & 66.7 & 57.9 & 48.1 & 41.9 \\
\hline $\begin{array}{l}\text { No. of households } \\
(' 000 \text { s) }\end{array}$ & 244 & 355 & 253 & 333 & 130 & 197 & 98 & 120 & 94 & 122 & 83 & 104 \\
\hline
\end{tabular}

Sources: WBO 1977, WBO 1985 
Table 5 illustrates the age-specific changes in housing preference. Two things are clear from this table. The first is the growth in demand for (another) dwelling. This is partly the result of the increased number of households in each cohort, shown in Table 3. The second is the increased demand for flats within every age group. It does not show, however, whether this increase is due to the changing age-specific household composition.

This is shown in Table 6 (in this table one-parent and multi-family households are not included because their numbers, particularly in 1977, were too small to provide statistically reliable estimates). The results of controlling for changes in household composition are striking. Couples without children show a stable and regular age-specific pattern of housing preference. Among the younger age groups there was a high preference for moving to a single-family dwelling. This is probably the result of two things. The first is that the young have not yet obtained a single-family dwelling. The second is that a large number of them intend to have children later on and already express a preference for single-family housing for this reason. Among the elderly, the preference for multi-family housing is probably due to the absence of stairs within that type of housing (they have a clear preference for flats with lift access (Serail, 1988)) and the decreasing ability of the elderly to maintain a garden. Couples with children show a similar pattern to that of couples without children, though a greater proportion prefer single-family dwellings, as one might expect.

Only among those households consisting of solitaries was there a (slight) increase in the preference for flats. This could be the result of unobserved changes in lifestyle. There are differences between the young and the old among this group too, though they are less marked than in the case of couples. Since the preference for flats as opposed to single-family dwellings also largely implies urban or suburban living, it is highly probable that the process of reurbanization, often presented as one of the dominant shifts in lifestyle during the 1980 s, is really a matter of changing attitudes to living arrangements.

The general conclusion that can be inferred from these analyses is that changes in housing preferences are not a direct expression of changing lifestyles as such. Changes in housing demand are more an expression of an underlying process of household development, which is determined to some extent by lifestyle dynamics. A comparison of households within specific age groups in 1977 to households with the same age in 1985 clearly demonstrates the shift towards individualization. Within each age group the proportion of people living alone rose significantly. It was not only the young who increasingly tended to remain single (the proportion of solitaries in this particular age-group tripled), it was also people aged 40 and over. Although in 1985 most households aged 31-54 contained children, the percentages are strikingly smaller than in 1977.

According to the figures in Table 6, successive cohorts clearly differ in their type of household composition. The overall pattern of an increase in the proportion of households consisting of solitaries should therefore not only be attributed to household evolution over time; it is also a consequence of the changing attitudes of new generations. The entry of new cohorts into the housing 
Table 6 Housing preference by age group in 1977 and 1985 for three household types (\%)

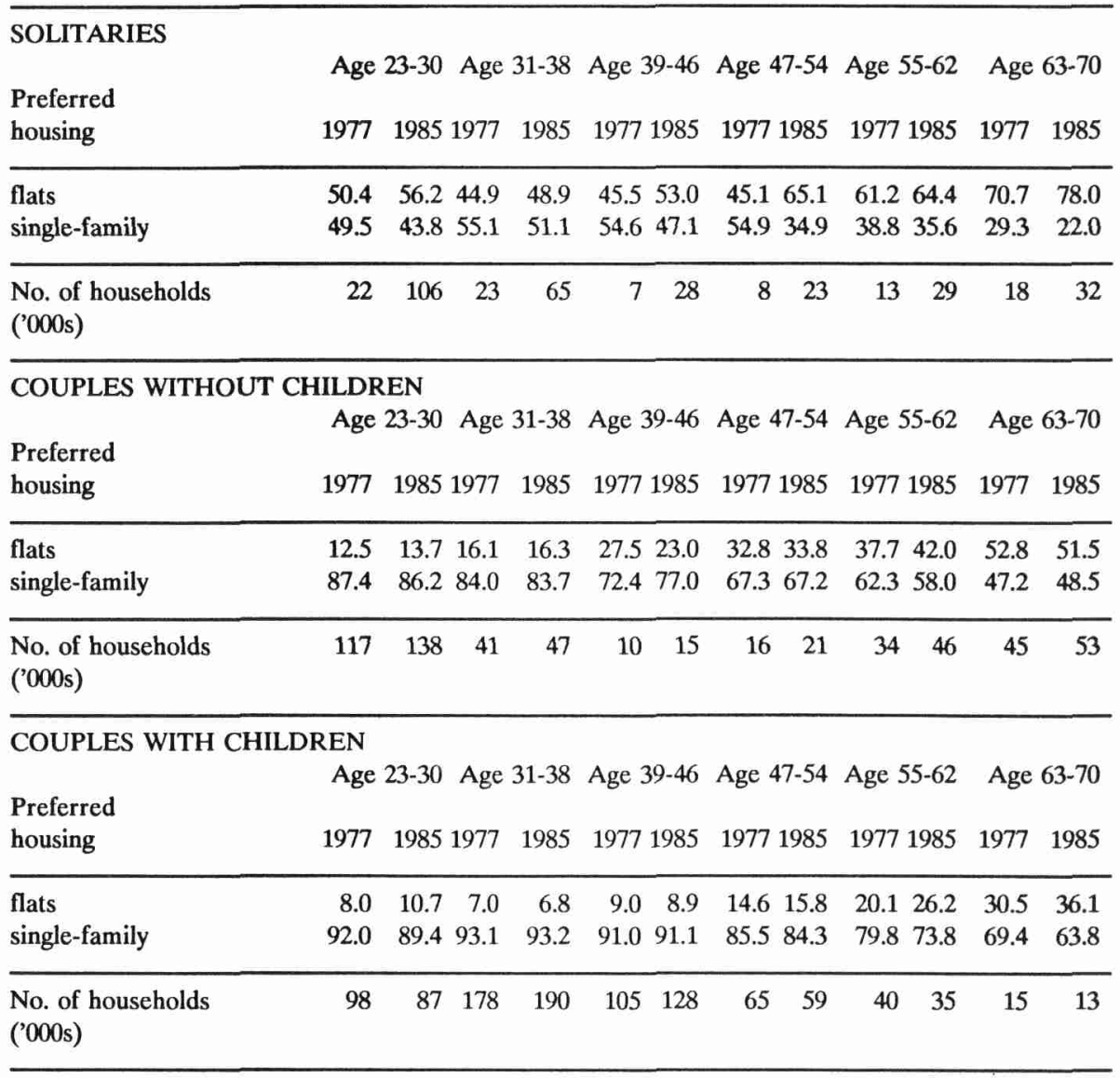

Sources: WBO 77, CBS (1987)

market and the progression of cohorts through the life cycle can bring about important transformations in society because of the different contexts in which these cohorts grow up.

\section{Future trends in household composition}

The conclusion drawn above, that changes in housing demand derive from changes in household composition, does not enable us to predict future patterns of housing demand unless we also have reliable household projections. Standard household projection models using headship rates are based on static ideas about 
life-cycle progression. Various attempts have been made to estimate trends in the development of headship rates over time, but with limited success. In the Netherlands a number of researchers have tried to construct simulation models which use transition probabilities (see Keilman, 1988, for an overview). This approach resembles to the cohort-component models used in population projections. Each component of household change (e.g. leaving the parental home, starting to cohabit, separation, widowhood) is analysed separately by estimating the probabilities that a transition will be made from one state to the other.

The crucial problem in household modelling is in quantifying hypotheses relating to future trends in transition probabilities. Changes in these probabilities over time can indicate two things. It can mean that fewer people participate in a particular process. The fall in parity progression rates during the 1970s provides a clear example. Fewer households decided to have children. But it can also mean that the age at which demographic events occur is changing. The decreasing age at which children leave the parental home (see Figure 1) does not affect participation rates (eventually they will nearly all leave), but it does affect when they leave home, and how long they spend in households other than the parental household. Figure 1 also provides a good example of how hypotheses concerning future changes can be generated. By analysing the difference in the "survival" function (the percentage of those in a particular age group still living with their parents) and by making assumptions about the rate at which a process occurs, future trends can be estimated. As Kuijpers-Linde and Hooimeijer (1989) have demonstrated, this provides an efficient and reliable estimate of future trends in household development. Their household projection pertained to the period 1982-2000. This provided an opportunity to check whether estimates of the agespecific distribution of persons over various household types were correct, by comparing them with the data from the Housing Needs Survey conducted at the end of 1985. The number of persons aged 18 or over still living with their parents was underestimated by 25,000 (out of a total of more than half a million). The number of people living alone was almost correct (overestimated by 8000 ), as was the number of widows (overestimated by 7000 ).

The results of the household projection are depicted in Figure 3. The number of households containing solitaries is likely to increase until 1995, after which the rate of increase will decline. The number of solitaries is likely to reach 2.5 million. The number of couples without children will also increase, especially in the early 1990 s, to a level slightly below 2 million in 2000 . A sharp decrease in the number of households with dependent children, from 2.6 million in 1982 to 2.1 million in 2000, is expected. After that, the number of families is expected to stabilise because of the stability in fertility rates since the early 1980s. The projection uses information about the choice of living arrangements for all cohorts born before 1960. Later cohorts are presumed to behave in the same way as the cohort born between 1955 and 1960. The reasonableness of this assumption must be questioned. Today's children will continue to choose different forms of cohabitation from those chosen by their parents; indeed, such 
Figure 3 Projected number and composition of households up to the year 2000

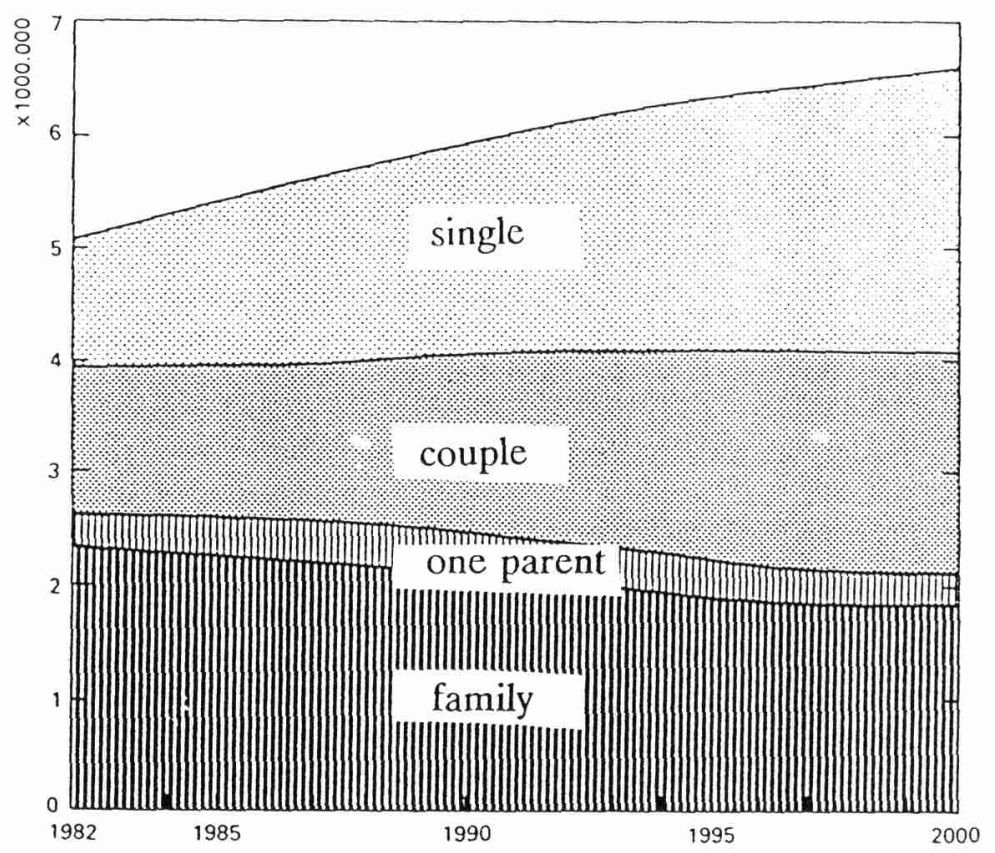

Source: Hooimeijer and Linde (1988)

a pattern of change has been an enduring one. A continuous monitoring of changes in lifestyles is therefore needed in order to enable us to predict the behaviour of new generations. This would improve the reliability of projections of household composition.

Once the basic choices people make (usually before the age of thirty) are known, the rest of their life course can be predicted with a large degree of accuracy. If we combine the dynamic lifestyle dimension with the relatively static life-cycle concept, an understanding of future trends may be possible. While short-term predictions of life cycles (households evolving over time) still hold, we include a dynamic element by taking account of changing attitudes to forms of cohabitation.

As we have shown, the changes in patterns of housing demand can be explained to a large extent by the variation successive cohorts make in their choice of basic living arrangements. A further increase in the demand for flats can therefore be expected. 


\section{Conclusion}

Changes in housing consumption can be related to changes in lifestyle. In this paper we have argued that, although lifestyle dynamics cannot be completely predicted, they should not entirely come as a surprise. Lifestyle has been defined as the values one holds with respect to work, living arrangements and consumption. There are two reasons why a pattern in lifestyle dynamics may be discerned. The first is that changes in societal response to the deviant behaviour of those adopting new values take time, and that the pattern of changes in values and norms is not random but points in a more general direction. The lifestyle changes mentioned in section two are all expressions of the more general process of individualization, which has been going on for a long time and will probably continue in the Netherlands, which lags behind other European countries in the extent to which the process of individualization has taken root. The second reason is that not every age group is affected by these changes in values to the same extent. The impact of innovations is felt most by those at the formative stage of their housing careers (Ryder, 1965). It is they who are most receptive to new ideas, while those already progressing through the life course will find it difficult to escape from the commitments of the past.

If present changes in household circumstances can be related to events from the past (e.g. the moment one enters the empty-nest stage is determined by past fertility), then future changes can be predicted on the basis of choices currently being made. The traditional life-cycle approach is wrong in its assumption that every cohort progresses along ordered sequences, but it does have the correct longitudinal perspective. Viewing lifestyle dynamics from this longitudinal perspective combines the advantages of both approaches. It accounts for the fact that society is highly dynamic, but it also allows one to make predictions concerning future trends which are more than merely speculative.

\section{References}

Feijter, H. de (1991), Voorlopers en achterblijvers bij demografische veranderingen, The Hague: NIDI.

Frinking, G.A.B. (1981), "De invloed van recente veranderingen in de wetgeving op het aantal echtscheidingen in Nederland", Bevolking en Gezin no. 2, pp. 163-178.

Glick, P.C. (1957), American Families, New York: John Wiley.

Hoog, C. de (1979), "Echtscheiding in Nederland", in Corver, C.J.J. et al. (eds), Gezin en samenleving, Amsterdam and Assen: SISWO and Van Gorcum.

Hoogvliet, A., and R.B. Jobse (1989), "De veranderende woonfunktie van de vroeg-20ste-eeuwse wijken", in Dieleman, F.M. et al. (eds), Met nieuw elan: de herontdekking van het stedelijk wonen, Delft: Delft University Press. 
Hooimeijer, P., and F.M. Dieleman (1986), Huishoudens in de reductiefase en de woonruimteverdeling, The Hague: Ministerie van Volkshuisvesting, Ruimtelijke Ordening en Milieubeheer.

Hooimeijer, P., and M.A.J. Linde (1988), Vergrijzing, individualisering en de woningmarkt, Utrecht: Geografisch Instituut.

Keilman, N. (1988), "Dynamic Household Models", in Keilman, N. et al. (eds), Modelling Household Formation and Dissolution, Oxford: Oxford University Press.

Kuijpers-Linde, M.A.J., and P. Hooimeijer (1989), "Dynamic Household Modelling", paper presented to the conference on Multi-Dimensional Demography, Zeist.

Leslie, G.R., and A.M. Richardson (1961), "Life cycle, career pattern and the decision to move", American Sociological Review no. 26, pp. 894-902.

Newel, C. (1988), Methods and Models in Demography, London: Belhaven Press.

Ratcliff, R.U. (1949), Urban Land Economics, New York: McGraw-Hill.

Rossi, P.H. (1955), Why Families Move, Glencoe: Free Press.

Ryder, N. (1965), "The cohort as a concept in the study of social change", American Sociological Review no. 30, pp. 843-855.

Serail, S. (1988), Huisvesting en (gewenste) verhuizingen van oudere huishoudens, The Hague: Ministerie van Volkshuisvesting, Ruimtelijke Ordening en Milieubeheer.

Shevky, E., and W. Bell (1955), Social Area Analysis, Stanford University Press. 